\title{
PHYTOSOCIOLOGICAL STUDY ON THE WEED COMMUNITIES IN GREEN SUGARCANE FIELD REFORM USING CONSERVATION TILLAGE AND OILSEED CROPS IN SUCCESSION
}

\author{
SoARes, M. B. B. ${ }^{1,{ }^{*}}$ - BiAnCo, S. ${ }^{2}$ - FinOto, E. L. ${ }^{1}$ - BolonheZI, D. ${ }^{3}-$ AlbuQuerQue, J. A. A. ${ }^{4}$ \\ ${ }^{1}$ Agribusiness Technology Agency of São Paulo (APTA), PO Box 24, Pindorama-SP, CEP \\ 15830-000, Brasil (phone: $+55-17-35722008 ;$ fax: $+55-17-35721592$ ) \\ ${ }^{2}$ São Paulo State University, Júlio de Mesquita Filho (UNESP), Jaboticabal, SP, Brasil \\ ${ }^{3}$ Agribusiness Technology Agency of São Paulo (APTA), Ribeirão Preto, SP, Brasil \\ ${ }^{4}$ Federal University of Roraima (UFRR), Boa Vista, Roraima, Brasil \\ *Corresponding author \\ e-mail: beatriz@apta.sp.gov.br \\ (Received $12^{\text {th }}$ Jul 2016; accepted $26^{\text {th }}$ Sep 2016)
}

\begin{abstract}
The objective of this study was to evaluate the weed community in green sugarcane field reform with three tillage managements and oilseed crops in succession. The experiment was conducted during the 2007/08 season on a sugarcane area harvested without prior burning in the last five cuts. Treatments were arranged in a split-plot design with four replications. Whole plots were conventional-till, minimum-till and no-till cropping systems and the subplots were fallow or crop rotation with peanut, soybean or sunflower. After 180 days of sugarcane harvest, weeds have been identified, the number of weeds. $\mathrm{m}^{-2}$ was counted and biomass of weeds above ground were taken. All data were subjected to analysis of variance using a split-plot model and the means were compared by Tukey's test at 5\% probability. The phytosociological indices were calculated. No-till system in the reform of green sugarcane significantly reduces the number and biomass of weeds. The use of soybean and peanuts in rotation with sugarcane in field reform was beneficial to controlling the weed population and suppressing weed species difficult to control as Cyperus rotundus and Commelina bengalensis.
\end{abstract}

Keywords: Arachis hypogaea; Glycine max; Helianthus annuus; minimum tillage; no-till

\section{Introduction}

Brazil is currently the largest producer of sugarcane (Saccharum spp. L.), being responsible for one third of that harvested in the world (FAO- STAT, 2009). A large part $(85 \%)$ of the sugarcane cropped in the country is concentrated in the south-central region, where São Paulo state is the main producer, with close to two-thirds of the Brazilian cropped area.

In Brazil, the traditional process of sugarcane harvesting is manually performed using the practice of pre-harvest burning. However more recently manual harvesting has been replaced by combiners that do not require the burning practice, in a system called green cane management. In São Paulo state $73 \%$ of sugarcane harvested refers to green cane harvesting (Canasat Project, 2015).

In various regions where sugarcane is grown, research on the agronomic implications of green-cane harvest with trash-blanket systems has been carried out. Leal et al. (2013) mentioning that in mechanized harvesting without burning, the straw blanket is left on the ground and there are several possible agronomic benefits such as increase of soil 
organic carbon content, inhibition of weed growth, nutrient recycling and reduction of soil water losses. Kingston et al. (2005) reported that are reduced preemergent herbicide use, tillage and soil erosion, as well as soil moisture conservation.

However, some of the benefits are countered by the suppressive effect of trash on ratoons, the harbouring of some diseases and insect pests and the difficulty of undertaking remedial tillage under a trash blanket (Meyer et al., 2005)

Due to not burning of sugar cane and mechanized harvesting make certain the presence of straw sugar cane for years in the area and bring the discussion on the use of the conservation tillage on renewal of plantations (Soares et al. 2012).

Traditional tillage systems can destroy soil structure and organic matter, and increase erosion potential. The adoption of minimum or no tillage planting and crop rotation systems as part of an improved sustainable cropping system, is seen as a major advance (Meyer et al., 2005).

Crop rotation is also seen as a desirable increase in productivity stands out among the benefits of crop rotation, in addition to aid in the control of pests, diseases and weeds; improvement in fertility and in the physical characteristics of the soil; improvement in efficiency in the use of water and nutrients; optimization of the use of machinery on the property; promotes diversification and consequent reduction of the economic risks (Christoffoleti et al., 2007). Nevertheless, in the most of the area of sugarcane renewal still is practiced the fallow land, i.e. the maintenance of uncultivated soil.

Weed community changes cannot be accounted for by a single variable because communities are influenced by multiple abiotic and biotic factors (Lègère and Samson, 1999). The knowledge of the weed community composition and also the combined weed management practices, will contribute to the required weed control efficacy, as well as to reduce the excessive herbicide application environmental risks (Fleck et al., 2008). The presence of straw blanket on the soil surface may modify the conditions of seeds germination and emergence of seedlings, due to the physical effect of cover and the release of allelopathic substances.

The benefits of most crops in succession in reducing weed infestation in the sugar cane renewal areas have been proven using the conventional till, in which the waste is incorporated into the soil. The studies concerning the comparison of tillage systems on weed population dont contemplate the succession of cultures and dont compare effects of different levels of soil disturbance in sugarcane monoculture (Mascarenhas et al., 2012).

Our objective was to determinate the phytosociological index values of a weed community in a sugarcane renewal area harvested without prior-burning at the last five cuts with three tillage managements and oilseed crops in succession.

\section{Materials and methods}

This study was conducted at Brazilian municipality of Novais, SP $\left(20^{\circ} 59^{\prime} 32^{\prime \prime}\right.$ south latitude, $48^{\circ} 55^{\prime} 07^{\prime \prime}$ 'west longitude and average altitude $555 \mathrm{~m}$ ) on an eutroferric redyellow acrisol soil. The last sugarcane harvest was done in the first fortnight of July. After harvesting, the amount of sugarcane straw was calculated at 14 t.ha $^{-1}$ using random samples of $1 \mathrm{~m}^{2}$. After defining the plots for renovation the areas were desiccated with glyphosate at a dose of 2,160 g.ha ${ }^{-1}$. 
The survey consisted in the evaluation of three cropping systems associated with fallow or an oilseed crop. Treatments were arranged in a split-plot design with four replications. Whole plots were conventional-till (CT), minimum-till (MT) and no-till (NT) cropping systems and the subplots were fallow or crop rotation with peanuts, soy or sunflower. Each plot was $8 \mathrm{~m}$ wide by $20 \mathrm{~m}$ long, and the whole plot was considered as floor area for randomly throwing the leaked sample frame $\left(1 \mathrm{~m}^{2}\right)$.

Conventional-till (CT) was established by the use of harrow + moldboard plow + graders; minimum-till (MT) was established by the use of vegetation chemical desiccation with glyphosate + plow levee with clod breaker (ASTMATIC 450); and notill (NT) was established by the use of glyphosate desiccation followed by planting without soil disturbance. The subplots were fallow and the oilseed crops: soybean cv. Monsoy 7908 RR, peanut cv. IAC-886 and sunflower cv. IAC-Iarama.

The subplots in fallow were kept with spontaneous vegetation without mowing or herbicide use. The peanuts crop of cultivar Runner IAC 886 (creeping cultivar of highyield potential; 125 day cycle) was sown in a $0.90 \mathrm{~m}$ spacing between rows in eight crop rows with planting density of 18 seeds per linear meter, the crops of soybean cv. Monsoy 7908 RR (cultivar resistant to glyphosate; 135-day cycle) and sunflower cv. Iarama (small and early maturity cultivar; 95-day cycle) were sown in the $0.45 \mathrm{~m}$ spacing, planting density of 16 seeds per linear meter for the soy and 3.6 seeds per linear meter for the sunflower, with a seeder with eight rows and a double mismatched disk system in the fertilizer distribution.

The fertilization was performed according to the analyses results and the technical recommendations. While conducting the test, chemical weed control was used for peanuts and soybeans. For peanut crop, imazapic was applied at the recommended dose of $98 \mathrm{~g}$ a.i./ha by the manufacturer ( $140 \mathrm{~g}$ of commercial product per hectare ) in preemergence of the peanut culture, i.e., 135 days before evaluation of the weeds. The procedure was a single application of glyphosate on soybeans at a dose of $2.16 \mathrm{~kg}$-eq acid. $\mathrm{ha}^{-1}, 50$ days after sowing, i.e. 116 days before evaluation of weeds. Ten days after the last crop (peanut) harvest, two points of $1.0 \mathrm{~m}^{2}$ per plot were sampled at random for weed evaluation. In each sample, the plants were identified; then their aboveground parts were cut, placed in paper bags and sent to the laboratory where they were dried in a forced air circulation oven and kept at $60^{\circ} \mathrm{C}$ for 72 hours for later weighing on a precision scale $(0.01 \mathrm{~g})$. Data were tabulated and statistically interpreted using analysis of variance, the means were compared by the Tukey's test $(p<0.05)$. Number of plants, dry matter and specific frequency data were used for determination of the phytosociological indices: relative density - RDe; relative dominance - RDo; relative frequency - RFr; importance value index - IVI; and relative importance value index - RIVI (Braun-Blanquet, 1979).

\section{Results}

Twenty-four weed species were found in the area, divided into 12 botanical families (Table 1). The families with the highest number of species found were Asteraceae, Amaranthaceae and Poaceae. No-till showed higher species richness (19), followed by conventional tillage (17) and minimum tillage (16). The plots planted with soybeans presented a higher number of species (17), followed by the fallow plots (16), the plots cultivated with peanuts (15) and sunflower plots (8). 
Table 1. List of species found in the area, botanical families, their respective experimental EPPO codes, soil management systems and sucession crops. Novais, SP, 2008

\begin{tabular}{|c|c|c|c|c|}
\hline Family & Scientific name & $\begin{array}{l}\text { EPPO } \\
\text { code }^{1}\end{array}$ & $\begin{array}{l}\text { Soil } \\
\text { Management }^{2}\end{array}$ & Crop $^{3}$ \\
\hline \multirow{3}{*}{ Amaranthaceae } & Amaranthus deflexus L. & AMADE & CT, MT, NT & $\mathrm{Pe}, \mathrm{Fa}, \mathrm{So}$ \\
\hline & Chenopodium ambrosioides $\mathrm{L}$. & CHEAP & NT & $\mathrm{Pe}, \mathrm{Fa}$ \\
\hline & Gomphrena globosa $\mathrm{L}$. & GOMGL & $\mathrm{CT}, \mathrm{MT}, \mathrm{NT}$ & $\mathrm{Pe}, \mathrm{Su}, \mathrm{So}$ \\
\hline \multirow{8}{*}{ Asteraceae } & Acanthospermum hispidum D.C. & ACNHI & NT & $\mathrm{Fa}$ \\
\hline & Ageratum conyzoides $\mathrm{L}$. & AGECO & CT, MT & $\mathrm{Su}, \mathrm{Fa}$ \\
\hline & Bidens pilosa $\mathrm{L}$. & BIDPI & CT, NT & $\mathrm{Pe}, \mathrm{Su}, \mathrm{So}$ \\
\hline & $\begin{array}{lll}\begin{array}{l}\text { Conyza } \\
\text { Cronquist }\end{array} & \text { canadensis } & \text { (L.) } \\
\end{array}$ & ERICA & $\mathrm{CT}, \mathrm{MT}, \mathrm{NT}$ & $\mathrm{Pe}, \mathrm{Su}, \mathrm{So}$ \\
\hline & Emilia fosbergii Nicolson & EMISO & $\mathrm{CT}, \mathrm{MT}, \mathrm{NT}$ & $\mathrm{Pe}, \mathrm{Fa}, \mathrm{So}$ \\
\hline & Galinsoga parvoflora Cav. & GASPA & $\mathrm{CT}$ & $\mathrm{Fa}$ \\
\hline & Parthenium hysterophorus L. & PYNHY & NT & $\mathrm{Fa}$, So \\
\hline & Tridax procumbens $\mathrm{L}$. & TRQPR & $\mathrm{CT}, \mathrm{MT}, \mathrm{NT}$ & Fa, So \\
\hline Commelinaceae & Commelina benghalensis L. & COMBE & $\mathrm{CT}, \mathrm{MT}, \mathrm{NT}$ & $\begin{array}{l}\mathrm{Pe}, \mathrm{Su}, \mathrm{Fa}, \\
\text { So }\end{array}$ \\
\hline Convolvulaceae & Ipomoea nil (L.) Roth & IPONI & NT & $\mathrm{Pe}$ \\
\hline Cyperaceae & Cyperus rotundus $\mathrm{L}$. & CYPRO & CT, MT, NT & $\begin{array}{l}\mathrm{Pe}, \mathrm{Su}, \mathrm{Fa}, \\
\mathrm{S}\end{array}$ \\
\hline Fabaceae & Aeschynomene rudis Benth. & AESSH & MT & $\mathrm{Fa}$ \\
\hline Malvaceae & Sida rhombifolia $\mathrm{L}$. & SIDRH & CT, MT, NT & $\begin{array}{l}\mathrm{Pe}, \mathrm{Su}, \mathrm{Fa}, \\
\text { So }\end{array}$ \\
\hline Phyllanthaceae & Phyllanthus tenellus Roxb. & PYLTE & MT, NT & $\begin{array}{l}\mathrm{Pe}, \mathrm{Su}, \mathrm{Fa}, \\
\text { So }\end{array}$ \\
\hline \multirow{4}{*}{ Poaceae } & Digitaria insularis (L.) Fedde. & DIGIN & $\mathrm{CT}, \mathrm{MT}$ & Pe, So \\
\hline & Digitaria sanguinalis (L.) Scop. & DIGNU & CT, MT, NT & $\mathrm{Su}, \mathrm{Fa}, \mathrm{So}$ \\
\hline & Eleusine indica (L.) Gaertn. & ELEIN & CT & $\mathrm{Su}$ \\
\hline & $\begin{array}{l}\text { Urochloa plantaginea (Link) } \\
\text { Hitchc. }\end{array}$ & BRAPL & CT, MT, NT & $\mathrm{Su}, \mathrm{Fa}$, So \\
\hline Portulacaceae & Portulaca oleracea L. & POROL & $\mathrm{CT}, \mathrm{MT}, \mathrm{NT}$ & $\mathrm{Pe}, \mathrm{Su}, \mathrm{So}$ \\
\hline Rubiaceae & Richardia brasiliensis Gomes & RCHBR & CT, MT, NT & $\begin{array}{l}\mathrm{Pe}, \mathrm{Su}, \mathrm{Fa}, \\
\text { So }\end{array}$ \\
\hline Solanaceae & Solanum americanum Mill. & SOLAM & $\mathrm{MT}, \mathrm{NT}$ & Pe, So \\
\hline
\end{tabular}

${ }^{I}$ EPPO code: also known as Bayer code, is an encoding system used by the European and Mediterranean Plant Protection Organization (EPPO) to designate plants, pests and pathogens that are important for agriculture, 2014.

${ }^{2}$ Soil management systems: $C T=$ Conventional tillage, $M T=$ Minimum tillage, $N T=$ No-till;

${ }^{3}$ Crops in sucession: $\mathrm{Fa}=$ Fallow, $\mathrm{So}=$ Soybean, $\mathrm{Pe}=$ Peanut, $\mathrm{Su}=$ Sunflower

When evaluating the number of weeds in the area (Table 2), there was a significant interaction between the whole plots (soil management) and subplots (succession crops). The subplots kept in fallow land or with peanut planting (Table 2) suffered a significant 
reduction in the number of weeds only when they were grown in no-till $(40.2 \%$ and $40.7 \%$, respectively), compared to conventional tillage.

Table 2. Average number of weeds in the three soil management systems for fallow and oilseed crops sowing in succession. Novais-SP, 2008

\begin{tabular}{|l|c|c|c|c|c|}
\hline \multirow{2}{*}{} & \multicolumn{3}{|c|}{ Number of plants } & \multirow{2}{*}{ F-Test } \\
\cline { 2 - 5 } & Fallow & Peanut & Sunflower & Soybean & \\
\hline Conventional tillage & $82,00 \mathrm{aB}$ & $81,00 \mathrm{aB}$ & $139,00 \mathrm{aA}$ & $101,50 \mathrm{aB}$ & \multirow{3}{*}{$79,6297 * *$} \\
Minimum tillage & $98,00 \mathrm{aA}$ & $72,00 \mathrm{aB}$ & $99,00 \mathrm{bA}$ & $71,00 \mathrm{bB}$ & \multirow{3}{*}{$20,0957^{* *}$} \\
\hline No-till & $49,00 \mathrm{bB}$ & $48,00 \mathrm{bB}$ & $73,00 \mathrm{bA}$ & $48,00 \mathrm{cB}$ & \\
\hline F-Test & \multicolumn{5}{|c|}{$6,7329^{* *}$} \\
\hline Interaction & \multicolumn{5}{|c|}{13,2} \\
\hline CV plot (\%) & \multicolumn{5}{|c|}{14,19} \\
\hline CV subplot (\%) & \multicolumn{5}{|c|}{} \\
\hline
\end{tabular}

${ }^{I}$ Means followed by the same letters, lowercase in the colums and uppercase in row, do not differ significantly by Tukey's test $(p<0.05)$; ** Significant at $1 \%$ probability by the F-test; $n$ s Nonsignificant

The effect of biomass of culture as mitigating circumstance of exposure of the soil is not noticed for sunflower and soybean crops. For the sunflower, the adoption of soil conservation tillage practices, either the minimum till or no-till, decreases significantly the number of weeds in up $47.5 \%$. The number of weeds in soybean culture differed significantly among themselves for the three systems of soil management. The number of weeds in no-till for soybean crop was about $46 \%$ less compared to conventional tillage and 34\% less in relation to the minimum tillage, which in turn was $30 \%$ less than in conventional tillage (Table 2).

The average values of the dry mass of weeds in the three soil management systems for fallow land and planting of oilseed crops in succession are observed in Table 3.

Table 3. Weeds dry matter in the three soil management systems for fallow and oilseed crops sowing in succession. Novais-SP, 2008

\begin{tabular}{|c|c|c|c|c|c|}
\hline & \multicolumn{4}{|c|}{ Dry matter ${ }^{1}\left(\mathrm{~g} \cdot \mathrm{m}^{-2}\right)$} & \multirow{2}{*}{ F-Test } \\
\hline & Fallow & Peanut & Sunflower & Soybean & \\
\hline Conventional tillage & $810,00 \mathrm{aB}$ & $455,00 \mathrm{aC}$ & $1035,00 \mathrm{aA}$ & $500,00 \mathrm{aC}$ & \multirow{3}{*}{$201,6448^{* *}$} \\
\hline Minimum tillage & $685,00 \mathrm{aA}$ & $495,00 \mathrm{aB}$ & $440,00 \mathrm{bB}$ & $585,00 \mathrm{aAB}$ & \\
\hline No-till & $305,00 \mathrm{bAB}$ & $240,0 \mathrm{bB}$ & $410,00 \mathrm{bA}$ & $230,00 \mathrm{bB}$ & \\
\hline F-Test & \multicolumn{5}{|c|}{$22,5525 * *$} \\
\hline Interaction & \multicolumn{5}{|c|}{$15,0216^{* *}$} \\
\hline CV plot (\%) & \multicolumn{5}{|c|}{11,15} \\
\hline CV subplot (\%) & \multicolumn{5}{|c|}{16,31} \\
\hline
\end{tabular}

${ }^{1}$ Means followed by the same letters, lowercase in the colums and uppercase in row, do not differ significantly by Tukey's test $(p<0.05)$; ** Significant at 1\% probability by the F-test; $n$ s Nonsignificant

For weed dry matter, as well as the number of weeds, there was a significant interaction between the whole plots and subplots. Thus, in the areas of conventional 
tillage, when they are left in fallow, the weed dry matter was higher than in the other treatments. No-till provided a dry mass of weed lesser than conventional tillage $(57.7 \%)$ and minimum tillage $(46.2 \%)$, which in turn proved to be intermediate, differing themselves also from conventional tillage (21.2\%). The sunflower subplots stand out from the other cultures, not differing of fallow plots.

In sunflower grown subplots, the use of any of the conservation tillage was efficient in the control of weeds in relation to conventional planting, reducing by up to $60.4 \%$ dry mass. For the other succession crops, only the no-till system promoted a significant decrease of weed dry mass .

Figures 1, 2 and 3 show the relative importance value index (RIVI) of the species found in the soil management systems for the area in fallow and oilseed crops cultivation in sucession.

Cyperus rotundus and Commelina benghalensis presented the highest relative importance value index (RIVI\%) in the areas cultivated with conventional soil management. The species Eleusine indica, Galinsoga parvoflora and Digitaria insularis were exclusive of this soil management. C. rotundus presented relative importance value index greater than $50 \%$ for fallow and sunflower subplots, subplots of growing soybeans and peanuts present $36.91 \%$ and $32.01 \%$ relative importance value index, respectively (Fig. 1).

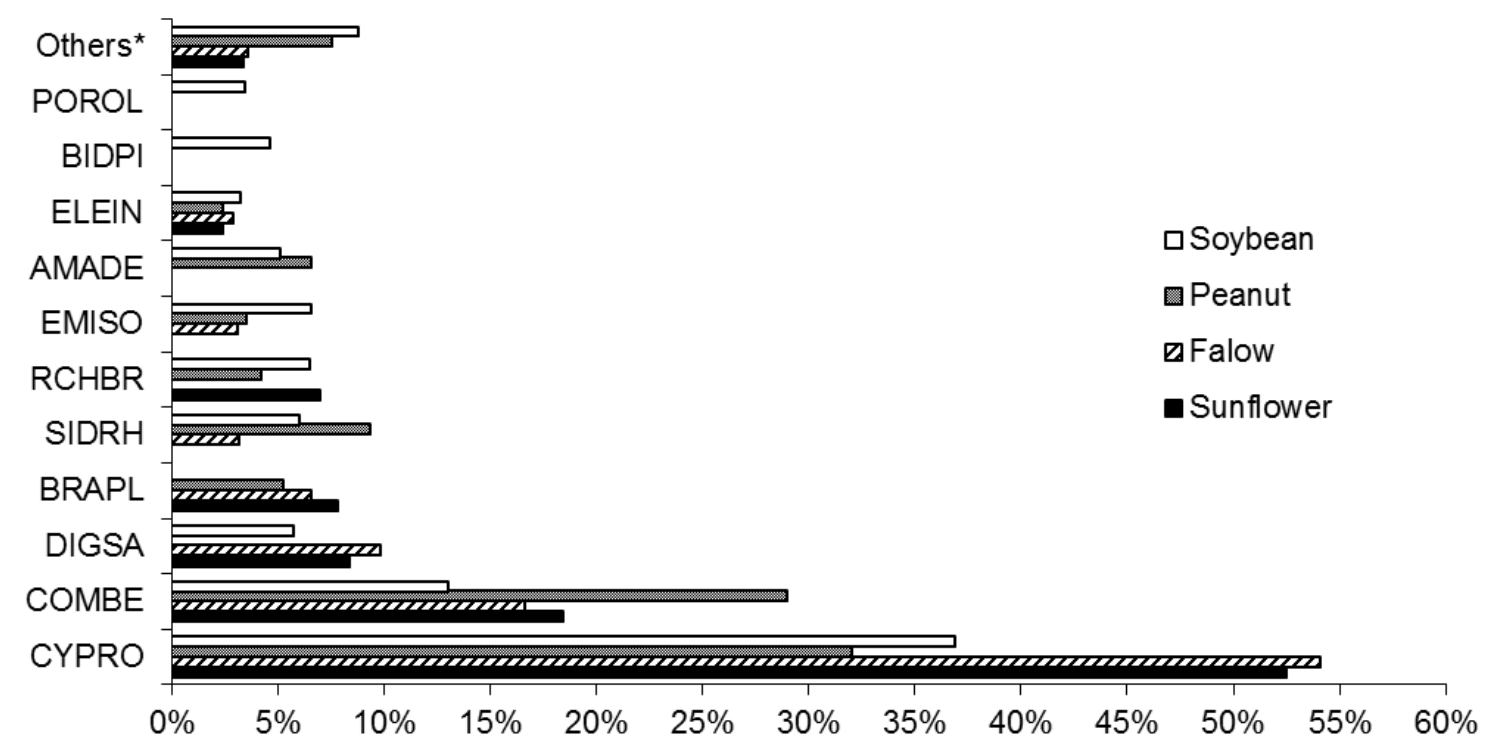

*Other species found in area, however, with low Relative Importance Value Index - RIVI: Ageratum conyzoides Galinsoga parvoflora, Conyza canadensis, Digitaria insularis, Tridax procumbens and Gomphrena globosa.

Figure 1. Relative Importance value index (RIVI\%) for the weed species in areas with conventional tillage in fallow plot or oilseed crop in sucession. Novais, 2008.

The species with greater relative importance value index (RIVI) in minimum tillage areas were $C$. rotundus, $C$. benghalensis, Richardia brasiliensis and Phyllanthus tenellus, the specie Aeschynomene rudis appeared exclusively in this soil management (Fig. 2). 


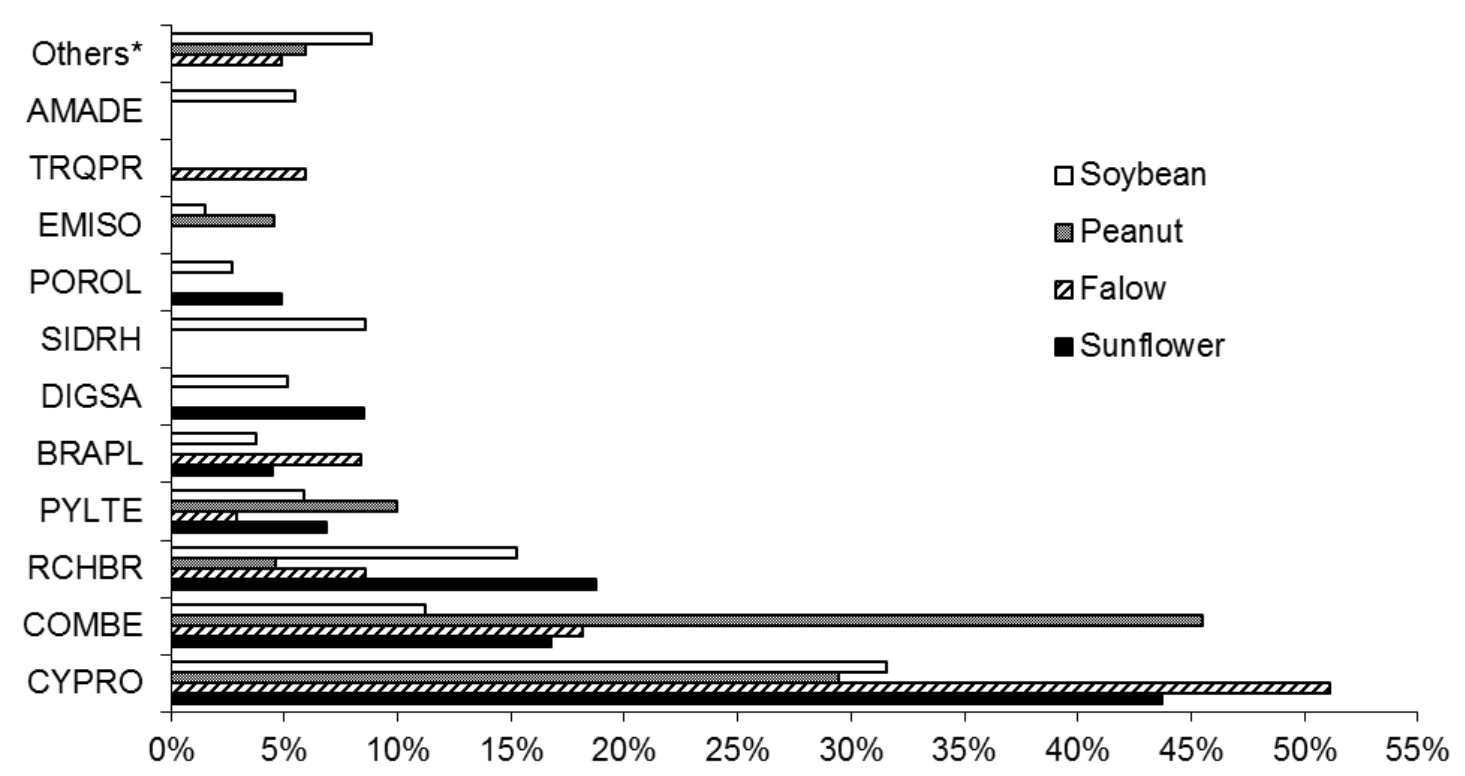

*Other species found in area, however, with low Relative Importance Value Index - RIVI: Conyza canadensis, Aeschynomene rudis, Ageratum conyzoides, Solanum americanum e Gomphrena globosa

Figure 2. Relative Importance value index (RIVI\%) for the weed species in areas with minimum-till in fallow or oilseed crops in succession. Novais, 2008.

In the areas of minimum tillage, as compared to conventional tillage, $C$. rotundus lost importance in the cultivation of peanuts. It maintained the value index of relative importance in the fallow land and had its importance increased in the sunflower and soybean crops. The species $C$. benghalensis presented greater relative importance in the culture of peanuts to this soil management system $(45.52 \%)$ and, because of its dominance, inhibited the development of other weeds. The species $R$. brasiliensis had its relative importance value increased in the minimum tillage, reaching relative importance value index of $18.73 \%$ and $15.22 \%$ in the areas of sunflower and soybean planting, respectively.

In the no-till area there has been greater variety of species and decreased value of RIVI of species considered difficult to control compared to conventional tillage.

For the areas kept in fallow land in no-till (Fig. 3), only C. rotundus reached relative importance value index above $30 \%(\mathrm{RIVI}=37.19 \%$ ), presenting greater homogeneity and lesser dominance of problematic species in relation to other studied soil management.

The value of relative importance index (RIVI\%) of C. rotundus in fallow areas in conventional soil management system is $54.13 \%$ decreasing to $13.82 \%$ when it is made the crop rotation with soybeans and no-till as soil management. Commelina benghalensis had greater importance in minimum tillage when the culture in succession was the peanut, however either use of no-till or crop rotation with soybeans show up as alternatives to the suppression of this weed, especially when used together (RIVI = $2.70 \%)$. 


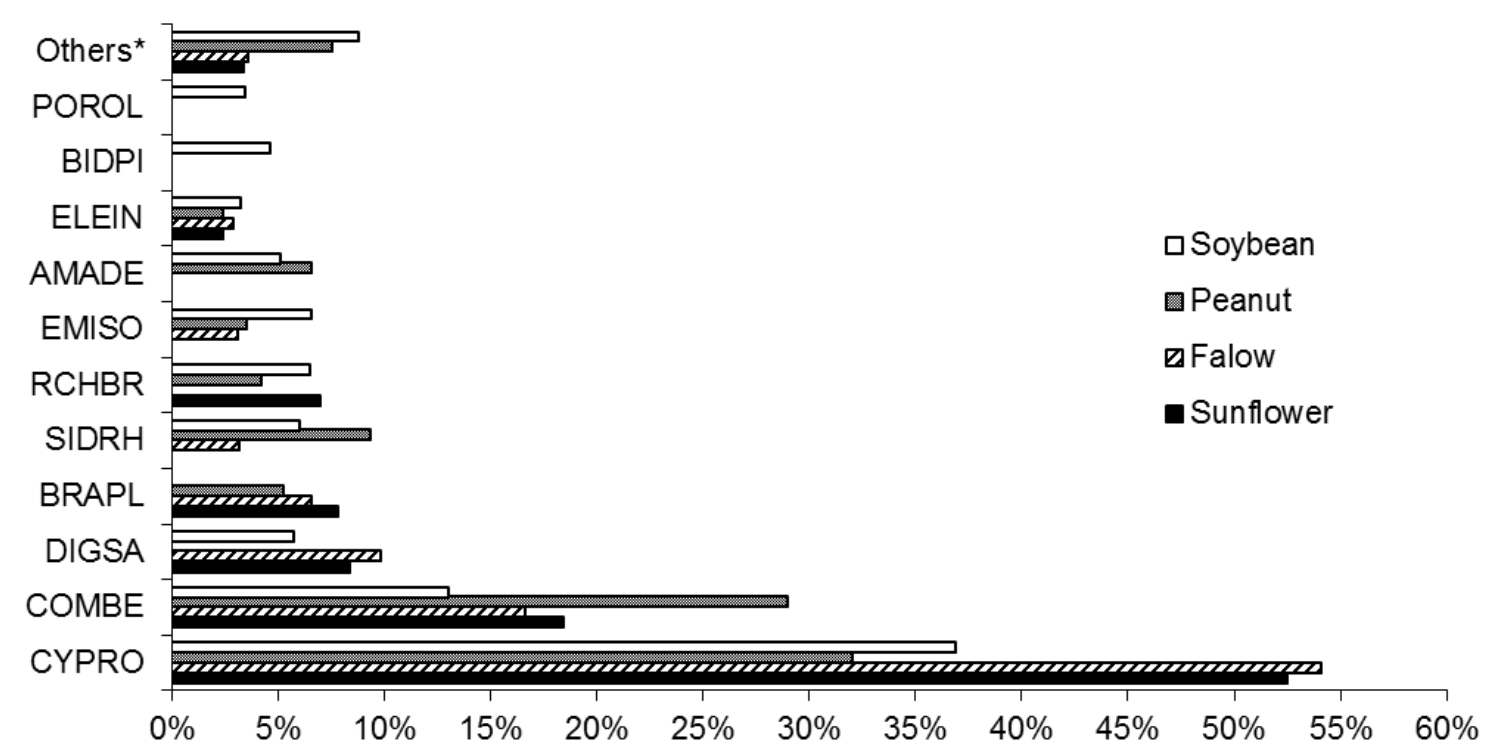

* Other species found in area, however, with low Relative Importance Value Index - RIVI: Parthenium hysterophorus, Solanum americanum, Chenopodium ambrosioides, Acanthospermum hispidum, Gomphrena globosa, Tridax procumbens, Ipomoea nil e Conyza canadensis.

Figure 3. Relative Importance value index (RIVI\%) to the weed species in areas with no-till in fallow or oilseed crops in succession. Novais, SP, 2008.

\section{Discussion}

There are difficulties for a proper management of weeds in sugarcane, however, the use of conservation tillage provides greater control of weed in relation to conventional management (Dantas et al., 2015).

Weed biomass, density, composition and temporal variation are closely associated with management practices, especially tillage (Nichols et al., 2015). Minimal or reduced tillage can shift weed composition from broadleaf to grass species (Swanton et al., 1999) or perennial weeds (Vogel, 1995), or increase weed species diversity when specific habitats for certain weeds are created (Murphy et al., 2006)

No-till resulted $45.9 \%$ reduction in the number of weeds if compared to conventional tillage and 33.9\% reduction in relation to the minimum tillage. Pereira and Velini (2003) highlight the greater efficiency of no-till system in cultural weed control, reducing the total number of individuals and the diversity of weed community

No-till soil management is more efficient, especially when there is no crop rotation (fallow) or the succession to the sugar cane provides less vegetal cover. No-till also provided a greater variability of weed species, and a smaller representation of species considered to be difficult to control in the culture of sugar cane, as the species of the families Poaceae and Cyperaceae. This soil management requires attention for development of morning-glory species (Convolvulaceae), also considered difficult to control.

The minimum tillage presented an intermediate behavior, especially dependent on crop grown in succession. In some cases, the minimum tillage is as efficient as no-till on weed suppression.

In most cases, greater exploitation of cover crop and crop residue mulches are discussed as a key strategy for suppressing weeds, particularly in warm climates where 
sufficient biomass may be generated to provide season-long weed suppression (Brainard et al., 2013).

Largest biomass of living mulch, use of a high residual effect herbicide in the peanut crop and the dominance of some weeds in fallow can have suppressed the effect of absence of mulch in the conventional tillage system making this system not significantly different from minimum tillage system. The exposure of the seed bank in conventional tillage and minimum tillage was an important factor to differentiate them from the no-till. The practice of not burn the waste of high $\mathrm{C} / \mathrm{N}$ ratio may favor the improvement of soil chemical properties over the other productive cycles of sugarcane (Carvalho et al., 2013).

It is possible to maintain problematic weeds under control in no-till, provided they are employees efficient rotation programs combined with appropriate soil management and chemical control. The use of no-till doesn't prevent the emergence of some species difficult to control, especially if the area is close to the focus of infestation, because the seeds in some cases are easily transported by wind.

The use of the sunflower crop resulted in greater numbers of weeds for all soil management systems used and the peanut crop resulted in lower incidence of weeds, this can be explained by plants architecture and by the use of early maturity cultivar of sunflower (95-day cycle), exposing the soil after its harvest for a longer period. The sunflower despite to present great biomass due to the high content of lignin and cellulose in their tissues not necessarily results in improved soil cover, by virtue of their waste consisting predominantly of stems or stalks (Sodré Filho et al., 2004). Cover crops or mulching only can suppress weeds effectively when the cover is adequate, and should cover at least $30 \%$ of the soil surface (CTIC, 1999).

According to Zimdahl (2013), the predecessor culture can interfere in the composition of the plant community, since some weed species are associated with greater intensity to certain cultures than others. Cardina et al. (2002) observed, in continuous system of 35 years, the crop rotation influenced more the seed bank of weeds than the soil preparation.

The mulch or crop cover may reduce or inhibit weed germination through the release of allelopathic compounds (Christoffoleti et al., 2007) or smothering of weeds (Thierfelder and Wall, 2010). Furthermore, weeds can be influenced by location, time, nitrogen management (Swanton et al., 1999), timing of cultivation, rainfall (Teasdale et al., 1991), crop residue management, crop rotations, harvest procedures and other aspects of the production system.

The greater the effect of crop biomass of succession in physical and chemical suppression of weed community, the smaller is the effect of soil tillage. Thus, in rotation with crops with great weed suppression capacity, the importance of soil management is not very significant. In sugarcane renewal areas kept fallow, choosing a conservation tillage is critical for weed control.

In agreement with the data obtained by Swanepoel et al. (2015), species composition also is changed. While few weed species made up the bulk of the importance in conventional tillage, these species represented only a fraction of the importance of weeds in the conservation tillage.

According to Kuva et al. (2007), C. rotundus has been the most important specie in green sugarcane harvested on the mechanized system. Monocots considered difficult to control as $C$. rotundus, $C$. benghalensis, Digitaria sanguinalis and Urochloa plantaginea are of great importance in the fallow areas. C. benghalensis also proved 
important in the areas of conventional tillage with peanut crop sown in succession, considering that the use of the herbicide imazapic is not recommended to control $C$. benghalensis. Soybean areas planted in conventional tillage have greater variety of weed species, thus reducing the importance of $C$. rotundus and promoting the appearance of other species such as Portulaca oleracea, Bidens pilosa, D. insularis and Tridax procumbens.

The specie $C$. rotundus was affected by the management of the chosen soil, gradually decreasing its importance as the soil management becomes more conservative, this weed is also affected by the culture of succession and the combination of these two factors.

C. benghalensis presented higher index of relative importance in the conservation tillage, however, the choice of combination of soil management and proper appear as viable alternatives to the removal of this weed.

Grasses were less important in areas where conservation tillage was adopted, particularly when the rotation with the peanut and soybean crops was made. The large biomass of cane straw and cultural practices used for these crops inhibited the development of the species of this family

Adaptable weed management (where continued monitoring of a system should influence the decision-making process and can be changed as needed, depending on available resources) or integrated weed management (combination of biological, chemical and mechanical weed management) should be practiced for allow effective weed control (Swanepoel et al., 2015).

\section{Conclusions}

Conservation tillage acts positively in the suppression of weeds, in green sugarcane reform areas.

Leguminous crops such as soybeans and peanuts in rotation with green sugarcane in reform areas were beneficial from the standpoint of control of weed population.

Crop rotation with the sunflower, from the point of view of weed population management, cannot be considered to be favorable in the studied conditions. It does not adequately control the populations of the same weeds compared to areas kept fallow.

\section{REFERENCES}

[1] Albuquerque, J.A.A.; Melo, V.F.; Soares, M.B.B.; Finoto, E.L.; Siqueira, R.H.S.; Martins, S.A. (2013): Fitossociologia e características morfológicas de plantas daninhas após cultivo de milho em plantio convencional no cerrado de Roraima. - Agro@mbiente On-line 7: 313-321. doi 10.18227/1982-8470ragro.v7i3.1392

[2] Brainard, D.C.; Haramoto, E.; Williams, M.M.; Mirsky, S. (2013): Towards a No-Till No-Spray Future? Introduction to a Symposium on Nonchemical Weed Management for Reduced-Tillage Cropping Systems. - Weed Technology 27(1): 190-192. doi:10.1614/WT-D-12-10001.1

[3] Braun-Blanquet, J. (1979): 'Fitossociologia - bases para el estudio de las comunidades vegetales.' - Blume: Madrid

[4] Canasat Project (2016): Sugarcane crop mapping in Brazil by Earth observing satellite images. São José dos Campos, SP, Brazil. Available at: <www.dsr.inpe.br/laf/canasat/en/>. Accessed on: 13 Jan, 2016 
[5] Cardina, J.; Herms, C.P.; Doohan, D.J. (2002): Crop rotation and tillage system effects on weed seedbanks. - Weed Science 50(4): 448-460. doi:10.1614/00431745(2002)050[0448:CRATSE]2.0.CO;2

[6] Carvalho, J.L.N.; Otto, R.; Franco, H.C.J.; Trivelin, P.C.O. (2013): Input of sugarcane post-harvest residues into the soil. - Scientia Agricola 70: 336-344. doi: 10.1590/S010390162013000500008

[7] Christoffoleti, P.J.; Carvalho, S.J.P.; López-Ovejero, R.F.; Nicolai, M.; Hidalgo, E.; Silva. J.E. (2007): Conservation of natural resources in Brazilian agriculture: implications on weed biology and management. - Crop Protection 26: 383-389. doi:10.1016/j.cropro.2005.06.013

[8] CTIC (Conservation Technology Information Centre) (1999): What's conservation tillage? CTIC Core 4 Program, Lafayette, IN, USA.

[9] Dantas, R.A.; Carmona, R.; Carvalho, A.M.; Reis, T.A.; Malaquias, J.V.; Santos, J.D.D.G. (2015): Dry matter production and weed control by intercropped legumes with sugarcane in organic cropping. - Pesquisa Agropecuária Brasileira 50(8): 681-689. doi:10.1590/S0100-204X2015000800006

[10] Ferreira, E.A.; Procópio, S.O.; Galon, L.; Franca, A.C.; Concenço, G.; Silva, A.A.; Aspiazu, I.; Silva, A.F.; Tironi, S.P.; Rocha, P.R.R. (2010): Weed management in raw sugarcane. - Planta Daninha 28(4): 915-925. doi: 10.1590/S0100-83582010000400025

[11] Fleck, N.G.; Lazaroto, C.A.; Schaedler, C.E.; Ferreira, F.B. (2008): Control of Alexandergrass (Brachiaria plantaginea) in soybean as a function of clethodim herbicide application rate and timing. - Planta Daninha 26(2): 375-383. doi:10.1590/S010083582008000200014

[12] Kuva, M.A.; Pitelli, R.A.; Salgado, T.P.; Alves, P.L.C.A. (2007): Phytosociology of weed community in no-burn sugar cane agroecosystems. - Planta Daninha 25(3): 501-511. doi:10.1590/S0100-83582007000300009

[13] Leal, M.R.L.V.; Galdos, M.V.; Scarpare, F.V.; Seabra, J.E.A.; Walter, A.; Oliveira, C.O.F. (2013): Sugarcane straw availability, quality, recovery and energy use: A literature review. - Biomass and Bioenergy 53: 11-19. doi:10.1016/j.biombioe.2013.03.007.

[14] Lègère, A.; Samson, D.N. (1999): Relative influence of crop rotation, tillage, and weed management on weed associations in spring barley cropping systems. - Weed Science 47: 112-122.

[15] Mascarenhas, M.H.T.; Lara, J.F.R.; Macêdo, G.A.R.; Viana, M.C.M.; Freire, F.M.; Karam, D. (2012): Effect of predecessor crops to sugarcane on floristic composition of weeds. - Revista Brasileira de Herbicidas 11(2): 241-248. doi: 10.7824/rbh.v11i2.170

[16] Meyer, E. ; Norris, C.P., Jacquin, E., Richard, C.; Scandaliaris, J. (2005): Burnt versus green cane harvesting: agricultural engineering challenges. Proceedings of ISSCT.25.

[17] Murphy, S.D.; Clements, D.R.; Belaoussoff, S.; Kevan, P.G.; Swanton, C.J. (2006): Promotion of weed species diversity and reduction of weed seedbanks with conservation tillage and crop rotation. - Weed Science 54: 69-77. doi: 10.1614/WS-04-125R1.1

[18] Murungu, F.S.; Chiduza, C.; Muchaonyerwa, P.; Mnkeni, P.N.S. (2011): Mulch effects on soil moisture and nitrogen, weed growth and irrigated maize productivity in a warmtemperate climate of South Africa. - Soil and Tillage Research 112: 58-65. doi:10.1016/j.still.2010.11.005

[19] Nichols, V.; Verhulst, N.; Cox, R.; Govaerts, B. (2015). Weed dynamics and conservation agriculture principles: A review. - Field Crop Research 183: 56-68. doi:10.1016/j.fcr.2015.07.012

[20] Pereira, F.A.R.; Velini, E.D. (2003): Tillage systems in the cerrado and dinamics of weed populations. - Planta Daninha 21(3): 355-363. doi:10.1590/S0100-83582003000300002

[21] Soares, M.B.B.; Finoto, E.L.; Bolonhezi, D.; Carrega, W.C.; Albuquerque, J.D.A.A. (2012): Plantas daninhas em área de reforma de cana crua com diferentes manejos do solo 
e adubos verdes em sucessão. - Agro@ mbiente On-line 6(1): 25-33. doi: 10.18227/19828470ragro.v6i1.683

[22] Sodré Filho, J.; Cardoso, A.N.; Carmona. R.; Carvalho, A.M.D. (2004): Fitomassa e cobertura do solo de culturas de sucessão ao milho na Região do Cerrado. - Pesquisa Agropecuária Brasileira 39(4): 327-334. doi: 10.1590/S0100-204X2004000400005

[23] Swanepoel, C.M.; Habig, J.; Thiebaut, N.; Swanepoel, L. H. (2015): Temporal variation in weed occurrence and biomass under conservation agriculture and conventional farming practices. - African Journal of Agricultural Research 10(41): 3921-3929. doi: 10.5897/AJAR2015.10089

[24] Swanton, C.J.; Shrestha, A.; Roy, R.C.; Ball-Coelho, B.R.; Knezevic, S.Z. (1999): Effect of tillage systems, $\mathrm{N}$, and cover crop on the composition of weed flora. - Weed Science 47: 454-461.

[25] Teasdale, J.R.; Beste, C.E.; Potts, W.E. (1991): Response of weeds to tillage and cover crop residue. - Weed Science 39: 195-199.

[26] Thierfelder, C.; Wall, P.C. (2010): Weed control in smallholder conservation agriculture. - Bulletin 6. CIMMYT. International Maize and Wheat Improvement Centre.

[27] Vogel, H. (1995): The need for integrated weed management systems in smallholder conservation farming in Zimbabwe. - Der Tropenlandwirt - Journal of Agriculture in the Tropics and Subtropics 96: 35-56.

[28] Zimdahl, R. L. (2013): Fundamentals of weed science. Academic Press, 650 p. 